\title{
Ancient Ceramic Analysis by Neutron Activation in Association with Multivariate Methods
}

\author{
U. M. Vinagre Filho ${ }^{1}$, R. M. Latini ${ }^{2}$, A V. B. Bellido ${ }^{2}$, A. Buarque ${ }^{3}$, and A. M. Borges ${ }^{2}$ \\ ${ }^{1}$ Instituto de Engenharia Nuclear - IEN-CNEN. Cid. Univ., \\ Ilha do Fundão Caixa Postal 68550, 21945-970, Rio de Janeiro, RJ, Brazil \\ ${ }^{2}$ Universidade Federal Fluminense, IQ-UFF. Outeiro São João Batista, sn. Valonguinho, 24020-150, Niterói, RJ, Brazil and \\ ${ }^{3}$ Museu Nacional - Depto. de Antropologia-UFRJ. Quinta da Boa Vista, São Cristovão, 20940-040, Rio de Janeiro, RJ, Brazil
}

Received on 23 January, 2005

\begin{abstract}
We report a comparative study of two archaeological sites, Bela Vista and Serrano, located in the Araruama region of the state of Rio de Janeiro, in Brazil. The elemental geochemical compositions of the ceramics from both sites were determined by Instrumental Neutron Activation Analysis (INAA). A statistical treatment of the data, using cluster analysis and principal component analysis, indicates that there are no correlations between these sites.
\end{abstract}

\section{INTRODUCTION}

The presence of ceramic sherds is always observed at the latest levels of the Sambaqui occupation in Rio de Janeiro, which were identified as belonging to the Una and Tupinambá archaeological groups [1,2]. In Brazilian archaeology it is interesting to investigate the contacts and relationship among horticulture, ceramics and fishermen, and hunter-gathering groups (FHG; Sambaquieiros) [1].

The disappearance of these FHG groups in some regions may has been associated with the arrival of new ceramic groups. In this investigation, we use analytical tools in order to identify and characterize collected ceramics fragments from the archaeological sites in the Araruama region. Ceramic objects are made from clays and often mixed with "tempers", which may be organic materials, sand, ceramic powder, shells, or other types of clays [3]. From a mineralogical point of view, a clay species and its respective chemical composition can show variations due to different geological conditions of formation and to the degree of isomorphic substitutions or exchanges by similarity and exchangeable cations. Therefore, the determination of the chemical composition of a particular sherd gives an indication of the specific clay source [4]. The characterization of the elemental chemical composition of the ceramic samples was done by using the nuclear technique of instrumental neutron activation analysis (INAA) $[5,6,7,8]$. For classification studies, the data were treated by two multivariate statistical methods, cluster analysis and principal component analysis.

\section{ARCHAEOLOGICAL SITES}

The ceramic materials used in this study were collected at the Condomínio Bela Vista and Serrano Archaeological Sites. Figure1 shows the intense Tupinambá occupation in this region. Polychromic ceramics with geometric decoration were mainly used for funerary and ornamental ware. Another archaeological study in the region, checking the elemental chemical composition, shows differentiation between domestic (cooking), ornamental, and funerary wares [9].

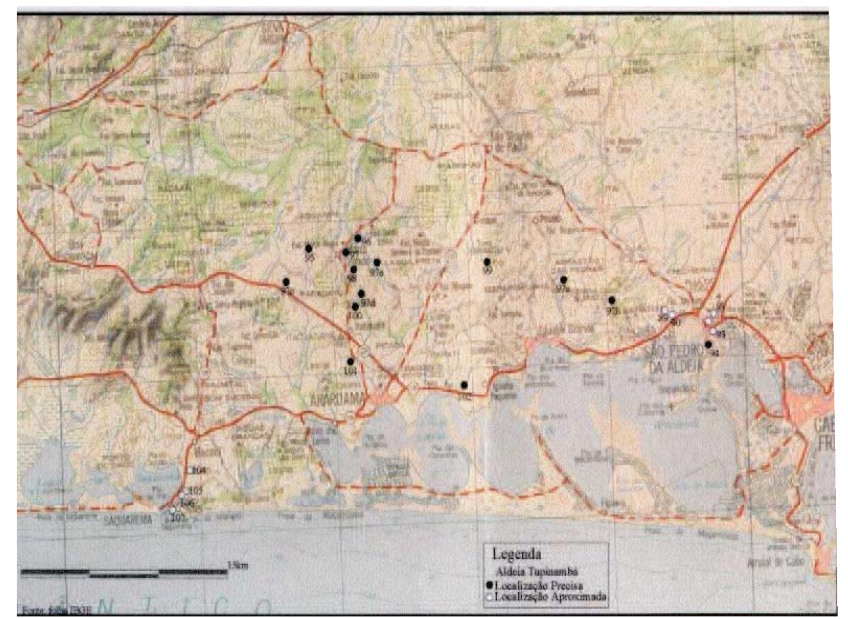

FIG. 1: Tupinambá archeological sites in the Araruama region

\section{INSTRUMENTAL NEUTRON ACTIVATION ANALYSIS}

We analyzed 18 collected ceramic fragments. The clay standard reference material was the Podmore Red Clay, which has an elemental concentration very close to our analyzed samples [6]. Approximately $200 \mathrm{mg}$ of representative ceramic fragments and standards were weighted and encapsulated in an appropriate polyethylene container for irradiation. In order to keep the same counting geometry, and to achieve the best results, we used approximately the same weight for samples and standards. The samples were irradiated at the IEAR1 research reactor of the Instituto de Pesquisas Energéticas e Nucleares (IPEN). The thermal neutron flux was of the order of $10^{12}$ n.cm $\mathrm{cm}^{-2} \mathrm{~s}^{-1}$. The irradiation time was in accordance with the half life of the measured radionuclides. The detection and measuring system consisted of a HPGe detector, a 4096 multichannel analyzer, an amplifier, as well as an associated electronic Ortec and Canberra, with 1,9 $\mathrm{keV}$ resolution 


\begin{tabular}{|c|c|c|}
\hline Element & $\begin{array}{c}\text { Bela Vista } \\
\text { Mean } \pm \sigma\end{array}$ & $\begin{array}{c}\text { Serrano } \\
\text { Mean } \pm \sigma\end{array}$ \\
\hline $\mathrm{Na}(\%)$ & $1.5 \pm 0.6$ & $0.4 \pm 0.2$ \\
\hline $\mathrm{K}(\%)$ & $1.3 \pm 0.4$ & $0.9 \pm 0.3$ \\
\hline $\mathrm{Sc}(\mathrm{ppm})$ & $11 \pm 2$ & $8.1 \pm 1.1$ \\
\hline $\mathrm{Cr}(\mathrm{ppm})$ & $28 \pm 7$ & $20 \pm 6$ \\
\hline $\mathrm{Mn}(\mathrm{ppm})$ & $80 \pm 21$ & $69 \pm 54$ \\
\hline $\mathrm{Fe}(\%)$ & $2.9 \pm 0.7$ & $2.7 \pm 0.3$ \\
\hline $\mathrm{Co}(\mathrm{ppm})$ & $4.3 \pm 1.6$ & $5.5 \pm 1.6$ \\
\hline $\mathrm{Rb}(\mathrm{ppm})$ & $57 \pm 27$ & $43 \pm 12$ \\
\hline $\mathrm{Cs}(\mathrm{ppm})$ & $3.0 \pm 0.6$ & $3.8 \pm 0.8$ \\
\hline $\mathrm{La}(\mathrm{ppm})$ & $61 \pm 14$ & $66 \pm 30$ \\
\hline $\mathrm{Ce}(\mathrm{ppm} \mathrm{x} 10)$ & $8.9 \pm 2.0$ & $14 \pm 2$ \\
\hline $\mathrm{Sm}(\mathrm{ppm})$ & $11 \pm 4$ & $16 \pm 5$ \\
\hline $\mathrm{Eu}(\mathrm{ppm})$ & $1.4 \pm 0.2$ & $1.9 \pm 0.2$ \\
\hline $\mathrm{Dy}(\mathrm{ppm})$ & $4.0 \pm 1.3$ & $5.1 \pm 0.9$ \\
\hline $\mathrm{Yb}(\mathrm{ppm})$ & $3.1 \pm 1.0$ & $2.7 \pm 0.3$ \\
\hline $\mathrm{Lu}(\mathrm{ppm})$ & $0.5 \pm 0.2$ & $0.4 \pm 0.1$ \\
\hline $\mathrm{Hf}(\mathrm{ppm})$ & $10 \pm 5$ & $7.1 \pm 2.8$ \\
\hline $\mathrm{Ta}(\mathrm{ppm})$ & $2.4 \pm 0.8$ & $1.5 \pm 0.3$ \\
\hline $\mathrm{Th}(\mathrm{ppm})$ & $17 \pm 2$ & $18 \pm 2$ \\
\hline $\mathrm{U}(\mathrm{ppm})$ & $3.2 \pm 0.8$ & $2.6 \pm 1.0$ \\
\hline
\end{tabular}

TABLE I: Characterization of the defined groups by chemical composition

to $\gamma$ - ray $1332,501 \mathrm{keV}{ }^{60} \mathrm{Co}$. We have used the technique of gamma-ray spectrometry and the computer code GRGAN [10] for data reduction. Special attention was given to choosing the photopeaks, i.e. ensuring that they were free from interference. The elements determined were $\mathrm{Ce}, \mathrm{Co}, \mathrm{Cr}, \mathrm{Cs}$, $\mathrm{Dy}, \mathrm{Eu}, \mathrm{Fe}, \mathrm{Hf}, \mathrm{Lu}, \mathrm{Mn}, \mathrm{Na}, \mathrm{Rb}, \mathrm{Sb}, \mathrm{Sc}, \mathrm{Sm} \mathrm{Ta}, \mathrm{Th}, \mathrm{Ti}, \mathrm{U}$, and $\mathrm{V}$

\section{STATISTICAL TREATMENT OF THE ANALYTICAL DATA}

The elemental concentrations obtained from INAA were used as variables in the statistical treatment. We used the SPSS packet [11], cluster analysis, and principal components analysis [12]. Initially, the data were normalized using " $\mathrm{z}$ scores," a transformation that generated new variables with zero average and standard deviation equal to one. In the cluster analysis, we used the square Euclidean distance as a measure in $n$-dimensional space, and the hierarchical means in the Ward subroutine (minimum variance). As a result of the cluster analysis, the samples were divided into two groups, the Bela Vista group and the Serrano group, determined from the chemical composition of these groups (Figure2: dendogram).

The characterization of these groups was made by the average and standard deviation of each one of the studied elements (Table I)

The groups were then analyzed in order to search for evidences of correlations between variables. The principal component analysis (PCA) was used to identify the significant elements that contributed to each cluster. The cluster analysis output is due to differentiated internal correlations. For the
Bela Vista group, the chemical elements in factor 1 (PCA 1) are $\mathrm{Dy}, \mathrm{Ta}, \mathrm{Yb}, \mathrm{Co}$, and $\mathrm{Fe}$; in factor 2 (PCA 2), they are $\mathrm{La}$ and Eu (Figure 3). For the Serrano group, the chemical elements in factor 1 (PCA 1) are $\mathrm{Mn}, \mathrm{Rb}, \mathrm{Na}$, and $\mathrm{Ce}$; in factor 2 (PCA 2), they are are Sm and Dy (Figure 4).

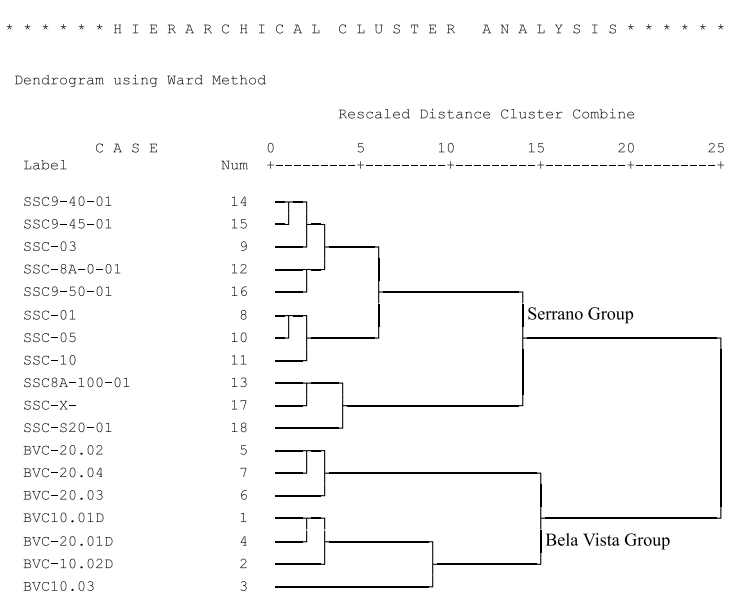

FIG. 2: Dendrogram based on the elemental composition from the archaeological sites Serrano ( SSC ) and Bela Vista( BVC )

\section{Sitio Bela Vista}

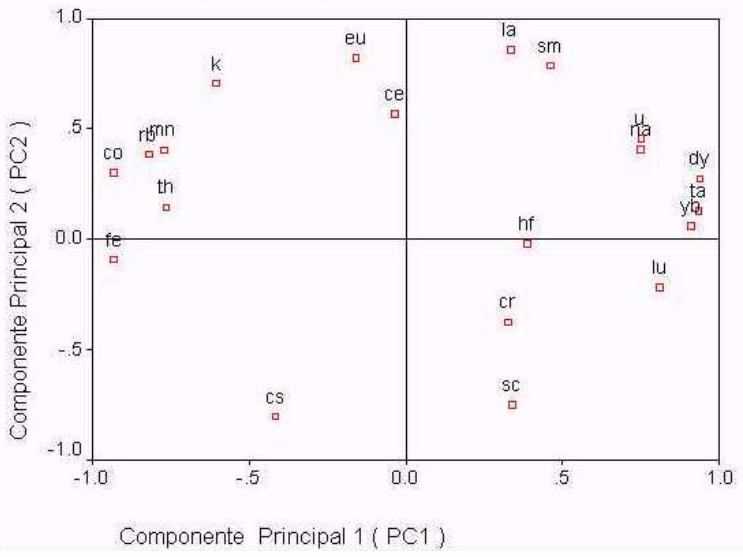

FIG. 3: Bela Vista Principal Components Analysis

\section{CONCLUSION}

The results obtained to date indicate clear differences in chemical composition of fragments from these two archeological sites. On the basis of the ceramic composition, it is suggested that the ceramic objects were made from different kinds of clay or using different methods of fabrication. 


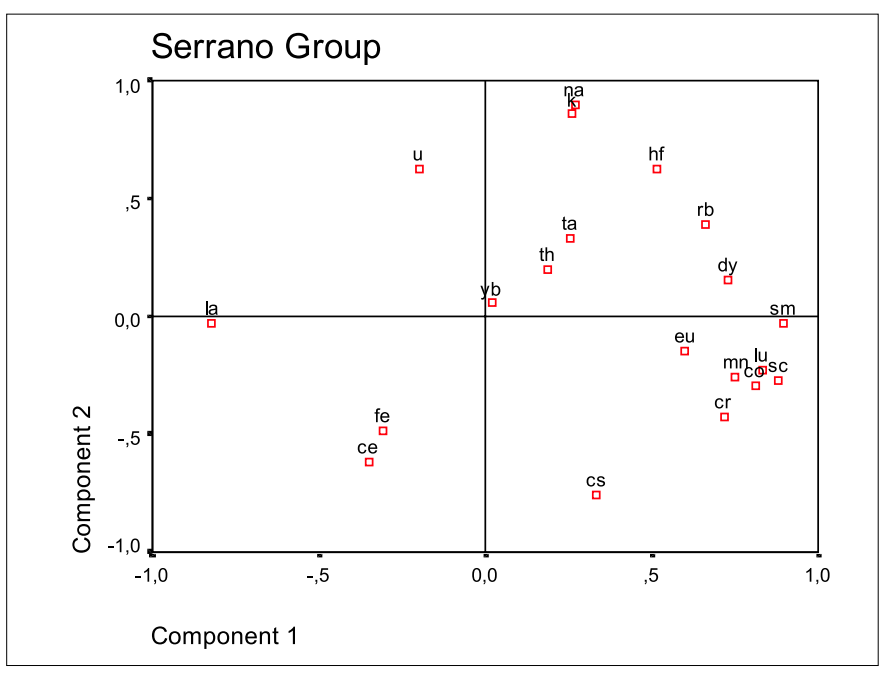

FIG. 4: Serrano Principal Components Analysis

\section{ACKNOWLEDGMENTS}

Thanks are due to Dr. M. Vasconcellos, Dra. M. Saiki and the Radiochemistry Group at IPEN for the NAA support.

\section{REFERENCES}

1. M. C. Tenório, (Organizadora), Pré-História da Terra Brasilis, Editora UFRJ, 376p. Rio de Janeiro, 1999.

2. M. D. Gaspar, A Pré-História do Estado do Rio de Janeiro: Sistemas Sociais Identificados até a Chegada dos Europeus, Bol. Mus. Nac., N. S., Antrop., n.60, p.1-22, Rio de Janeiro, 1997.

3. U. M. Franklin, and V. Vitali, The Environmental Stability of Ancient Ceramics, Archaeometry, London, v.27, n.1, p 3-15, 1985.

4. R. M. Latini, A. V. B. Bellido, Dias Jr., and L. F. Bellido, Determining the Provenience of Prehistoric Cera- mic Artifacts from the Amazon Basin Using Geochemical Tracers, Environmental Geochemistry in Tropical and Subtropical Environments, Springer-Verlag, v.1, p. 93-99, 2004.

5. R. M. Latini, Caracterização, Análise e Datação de Cerâmicas Arqueológicas da Bacia Amazônica através de Técnicas Nucleares, Ph. D. Thesis, Universidade Federal Fluminense, Niterói, Brazil, 157p, 1998.

6. A. V. B. Bellido, Neutron Activation Analysis of Ancient Egyptian Pottery, Ph. D. Thesis, University of Manchester, Manchester, UK, 324p, 1989.

7. R. P. Paiva, C. S. Munita, and M. A. Alves, Potencialidade da AANI em Estudos de Cerâmicas Arqueológicas, VII Congresso Geral de Energia Nuclear, CGEN-ABEN, Belo Horizonte, MG, Brazil, 27-30 October, 1998.

8. R. M. Latini, A. V. B. Bellido Jr., M. B. A. Vasconcelos, and O. F. Dias Jr., Classificação de cerâmicas arqueológicas da Bacia Amazônica, Quimica Nova 24, 724 (2001).

9. R. M. Latini, A. V. B. Bellido Jr., and A. Buarque, Estudos de classificação e datação de cerâmicas arqueológicas do Estado do Rio de Janeiro, V Congresso de Geoquímica dos Países de Língua Portuguesa and VII Congresso Brasileiro de Geoquímica, 333-335, 1999.

10. G. R. Gilmore, Sources Uncertainty in Neutron Activation Analysis of Pottery, Technical Report, Universities Research Reactor, Risley (1983)

11. SPSS Inc. 444, North Michigan Ave. Chicago IL, 60611.

12. A. V. B. Bellido, M. R. Chandratillake, and V. I. Robinson, Cluster Analysis in Ceramic Provenance Studies: Methods for Dealing with Elemental Correlations (in preparation). 